\title{
Ekumensko srečanje s predstavniki Ruske pravoslavne cerkve (Stična, 27. 7. 2019)
}

\author{
Ecumenical Meeting with the Representatives \\ of the Russian Orthodox Church \\ (Stična, Slovenia, July 27, 2019)
}

V okviru vsakoletnih državnih in cerkvenih slovesnosti, povezanih s t. i. Rusko kapelico oz. z ohranjanjem spomina na med prvo svetovno vojno umrle ujetnike ruske imperialne vojske, ki jih je pod prelazom Vršič nad Kranjsko Goro zasul snežni plaz, je od 25. do 29. julija 2019 v Sloveniji gostovala delegacija Ruske pravoslavne Cerkve. Tokrat jo je vodil komaj štiriintridesetletni Vladika Siluan (Nikitin), peterhofski škof, vikar sanktpeterburškega metropolita in rektor Duhovne (teološke) akademije Ruske pravoslavne cerkve v Sankt Peterburgu. Med pomembnejšimi dogodki na sporedu obiska omenjene delegacije so bili ekumenski pogovori, ki so dopoldne v petek, 27. julija, potekali v prostorih cistercijanske opatije v Stični. Pogovorov so se udeležili in jih poleg predstavnikov Ruske pravoslavne cerkve sooblikovali predstavniki Katoliške cerkve v Sloveniji pod vodstvom upokojenega celjskega škofa dr. Stanislava Lipovška, predstavniki Zagrebško-ljubljanske metropolije Srbske pravoslavne cerkve pod vodstvom metropolita Porfirija (Perića) in predstavniki Evangeličanske cerkve v Sloveniji pod vodstvom mag. Geze Fileja. Vsaka od navedenih strani, udeleženih v pogovoru, je podala svoje mnenje o današnjem stanju ekumenske teologije ter o drugih ekumenskih prizadevanjih na različnih ravneh cerkvenega, kulturnega in družbenega življenja. 
Ekumensko srečanje se je začelo s skupno molitvijo v stiški baziliki, čemur je sledil priložnostni koncert mešanega pevskega zbora Sanktpeterburške duhovne akademije, ki sta ga zaokrožila kratka pozdravna nagovora stiškega priorja dr. Nikolaja Arackega Rosenfelda in škofa Siluana. Drugi in hkrati osrednji del ekumenskega srečanja so predstavljali poltretjo uro trajajoči in vsebinsko zgoščeni ekumenski pogovori, kjer je kot prvi spregovoril škof Siluan. Največ besed je namenil ruskim pravoslavnim teološkim akademijam in drugim cerkvenim šolam, pri čemer je izpostavil izziv (ne) ustreznega ohranjanja pravoslavne istovetnosti. Po njegovem prepričanju nekateri (pretežno laiški) profesorji, ki kot zaposleni na teoloških ustanovah nimajo v zadostni meri razvite »cerkvene zavesti«, vse večji poudarek namenjajo različnim humanističnim vedam, s čimer škodujejo osnovni vedi oz. usmeritvi - tj. teologiji, umeščeni v izročilo in življenje Pravoslavne cerkve. V podobnem duhu naj bi tudi država, s katero Ruska pravoslavna cerkev sicer dobro sodeluje, spodbujala teološke ustanove, naj svoje študente bolj pripravljajo na poklic učitelja ali humanitarnega delavca kakor pa za duhovnike in druge služabnike Cerkve. Škof Siluan je nato izrazil željo po vzpostavitvi stikov in sklenitvi sporazuma o sodelovanju med Sanktpeterburško duhovno akademijo in Teološko fakulteto Univerze v Ljubljani. Podprl je tudi zamisel, da bi tovrstno ekumensko prizadevanje nadgradili s srečanji oz. izmenjavami na ravni mladinske pastorale. Zagrebško-ljubljanski metropolit Porfirije, ki hkrati opravlja službo profesorja na Pravoslavni teološki fakulteti Univerze v Beogradu, je poudaril pomembnost neločljive povezanosti med teologijo, molitvijo in Cerkvijo. Za iztočnico si je izbral misel sv. Gregorija iz Nazianza: »Govori samo takrat, kadar tvoj govor pove več kakor tvoj molk. "Zaključil pa je z mislijo sv. Evagrija Pontskega: „Če si teolog, boš resnično molil, in če boš resnično molil, si teolog." Metropolit Porfirije se je strinjal s škofom Siluanom glede napetosti med teologijo in drugimi humanističnimi vedami na današnjih pravoslavnih in še bolj katoliških - teoloških fakultetah. Sebe je označil za »konservativnega«teologa, ki pri teološkem študiju daje prednost jedrnim teološkim (zlasti patristično-dogmatičnim) predmetom. Zavzel je stališče, da morajo teološke fakultete $\mathrm{v}$ prvi vrsti oblikovati duhovnike in druge služabnike Cerkve - teologija naj bo torej v službi Cerkve in sestavni del njenega življenja, ne toliko vrhunska znanstvena ustanova, ki bi se opirala zgolj na razum, ali po drugi strani šola za humanitarne ali psihoterapevtske delavce. 
Naslednji govornik, mag. Geza Filo, je izrazil veselje nad dejstvom, da je Vršič kot kraj spomina na žrtve in tragedijo prve svetovne vojne v zadnjih desetletjih postal kraj srečevanja med narodi in različnimi krščanskimi Cerkvami. Opozoril je, naj se vsi kristjani resnicoljubno soočijo s procesi in učinki t. i. razkristjanjenja ter na tak način z osebnim pričevanjem, izhajajočim iz življenja po evangeliju, storijo več za ponovno odkritje »evropske duše«. Dr. Robert Petkovšek, dekan Teološke fakultete Univerze v Ljubljani, je svoj nagovor začel z omembo stoletnice ljubljanske teološke fakultete, nato pa je predstavil njeno današnje poslanstvo in podprl možnost povezovanja s Sanktpeterburško duhovno akademijo. Matevž Mehle, direktor zavoda Katoliška mladina oz. koordinator slovenske katoliške mladinske pastorale, je izrazil željo po sodelovanju med slovensko katoliško in rusko pravoslavno mladino, pri čemer bi lahko kot izhodišče služil slovenski mladinski festival »Stična mladih«. Dr. Anton Štrukelj, upokojeni profesor ljubljanske teološke fakultete, je predstavil svoj osebni vidik sodelovanja med Katoliško in Pravoslavno cerkvijo ter izpostavil dejstvo, da je pred dobrimi tridesetimi leti dva semestra predaval na katoliški teološki šoli v Sankt Peterburgu. Teologa mlajše generacije, dr. Simon Malmenvall, ki je vse nagovore tolmačil iz slovenščine v ruščino (in obratno), in frančiškan Jan Dominik Bogataj, sta poudarila svojo zavzetost in ljubezen do vzhodne teologije. Celoten pogovor je vodil dr. Bogdan Dolenc, tajnik Slovenskega ekumenskega sveta in upokojeni profesor ljubljanske teološke fakultete.

Sodobno stanje ekumenskega dialoga med katoliško in Rusko pravoslavno cerkvijo, kakor se odraža v različnih dogodkih (ekumenskih pogovorih, znanstvenih konferencah ipd.), skupnih dokumentih (npr. Skupni izjavi papeža Frančiška in patriarha Kirila iz leta 2016) in javnih odzivih njenih visokih predstavnikov, je mogoče povzeti s pomočjo prepoznavanja določenih ponavljajočih se tem oz. stališč. Prvo temo oz. stališče in hkrati pomemben napredek na področju katoliško-pravoslavnega dialoga predstavlja kontinuiteta pontifikatov Benedikta XVI. in Frančiška, ko se ruski pravoslavni strani zdi, da se je Katoliška cerkev verjetno dokončno odpovedala uniatski metodi. To je povezano z dejstvom, da sedanji Rim v javno manj izpostavljeni meri kakor v času Janeza Pavla II. podpira želje in prizadevanja Ukrajinske grkokatoliške cerkve, ki jo Ruska pravoslavna cerkev razume kot »moteč« dejavnik v zgodovini katoliško-pravoslavnih odnosov na območju vzhodne Evrope, njen ponoven razcvet po razpadu Sovjetske zveze pa vsaj nekoliko pristransko prikazuje kot politično 
pogojeno »širjenje« na tradicionalno rusko pravoslavno kanonično ozemlje v okviru Ukrajine in Belorusije. Podobno previdno ravnanje Katoliške cerkve odraža odsotnost njenega vmešavanja v aktualni pereči spor med moskovskim in konstantinopelskim patriarhatom glede vzpostavitve avtokefalne Pravoslavne cerkve na ozemlju Ukrajine. Večje zaupanje pravoslavne Moskve do katoliškega Rima se kaže tudi v skupnih nastopih za zaščito verske svobode in tradicionalne družine, ki v zahodnem svetu vse bolj izgublja svoj (normativni) pomen, ter za zaščito preganjanih kristjanov $\mathrm{v}$ arabskih in drugih večinsko muslimanskih državah, ki jim zahodni medijski in drugi mnenjski voditelji ne posvečajo veliko pozornosti - prav to med drugim izrecno izpostavlja prej omenjena Skupna izjava. Tretjo temo, pri čemer se trenutno zdi, da jo bolj od Rima izpostavlja Moskva, pa je mogoče prepoznavati v opozorilih ruskih pravoslavnih dostojanstvenikov o nevarnosti take sekularizacije, ki ne prihaja več zgolj »od zunaj«, temveč (lahko) poteka tudi znotraj Cerkve same. Omenjena obrambna drža se med drugim kaže v podpiranju kakovostne, a hkrati z izročilom in molitveno-liturgičnim življenjem usklajene teološke izobrazbe, kar je bilo mogoče slišati tudi v okviru ekumenskih pogovorov v Stični. 